\title{
$\beta$ アルミナを主體さする硝子坩堝の研究
}

\section{加藤 左 織・山 内俊吉}

1. 緒言

買に本誌に $\beta$ アルラナの形態，諸怕狀並にその生成過程中

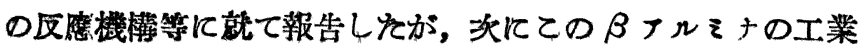
的利用法儿就て研究老行つて見た。

アァルミナの生成はパイヤー法アルミナを燒結义は熔融す る際㱠ど免れ得ないるの之されてるるが，從來ての $\beta$ フルミ 士の存在は工業的に極めて厄介視されて來たるのであつて賽

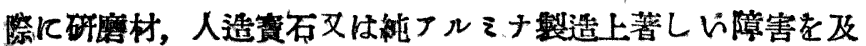

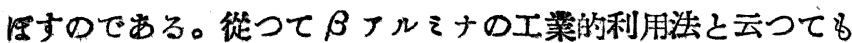

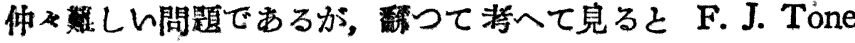
(Ind. Eng. Chem, 1938, 30, 232 242) Ф提唱に上れば $\beta$ フ

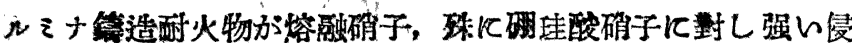
领抵抁性を示与事を进べ, 及 A. P. Thompson (Ceram. Ind, 1927,29, 360) 伎U H. N. Baumann \& A. A. Turner (Jour:Am. Ceram. Soc., 1940, 23, 3314) ほ $\beta$ アルえナを

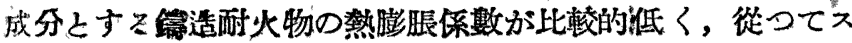

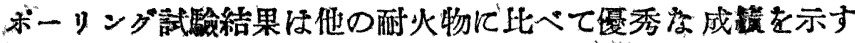

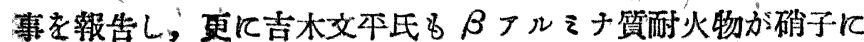

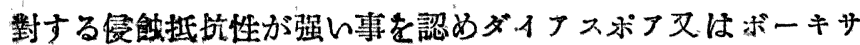

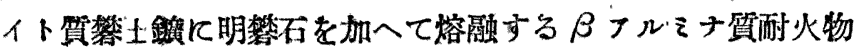
の製造法て對して特許を取つてなる。

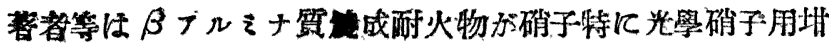
嵪としての性能を知るために種々の筫驗を行つた。

2. 素地土の調製並にその理化學性

訆驗用素地として揢融 $\beta$ アルぇナを主成分とする素地と夫

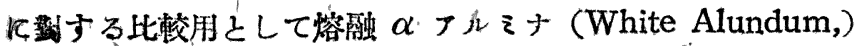
ダイアスポフ烺燒物，蠟石燒粉，木節燒粉等を夫主成分之 する各種の素地老調製して見民。使用原料の化學成分及ひ耐 火度を示せば次の第 1 表の樣である。质使用した $\beta$ ァルミ ナ結晶は電魚揢融による白色アランダム製造の際副生した熔 融物である。 次に素地土の淈合割合は，炏の第 2 表に示す樣に結合劑は
木節粘士 $20 \%$ ，蛙目粘士 $10 \%$ そ一定にしてをんて，ての結 合劑 $30 \%$ 凡對して上記 5 種の粉末 (粉末度は全て $0.5 \mathrm{~mm}^{\circ}$ 孔 飾通過应度) $70 \%$ を加へた。

第 2 表 素地土の調合割合

\begin{tabular}{|c|c|c|c|}
\hline 符竹 & 詋合物割 & 蟯粉( $0.5 \mathrm{~mm}$ 飾通過分) & $\begin{array}{c}\text { 結 合 狧部 } \\
30 \%\end{array}$ \\
\hline & B & 揢融 $\beta$ アルミナ結晶粉末) & \\
\hline & $\mathbf{A}$ & 揢融 $\alpha$ アルミナ粉末 & \\
\hline & $\mathbf{D}$ & ダイアスポー燒粉。 & $\begin{array}{l}\text { 辰的粘土 } 20 \% \\
\text { 蛙日粘土 } 10 \%\end{array}$ \\
\hline & $\mathbf{R}$ & 繝 石 脿 粉 & \\
\hline & $\mathrm{K}$ & 木簛粘士シャモット & \\
\hline
\end{tabular}

之等の葀合原料を以て先づ物理性測定用の供試體を成形し 燒成したが，素地の藏孔率教なるへく等しい狀態にするため 素地每に燒成溫度を變へて行つた。その憢成溫度度び燒成素 地の化举成分は第 3 表に示す通りである。

第 3 表 各秦地の溹成溫度及び焼成菜地の化學成分

\begin{tabular}{|c|c|c|c|c|c|c|c|c|}
\hline 午 & 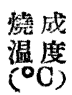 & $\begin{array}{l}\mathrm{S}_{2} \mathrm{O}_{2} \\
(\%)\end{array}$ & $\begin{array}{c}\mathrm{A!}_{2} \mathrm{O}_{3} \\
(\%)\end{array}$ & $\begin{array}{c}\mathrm{Fe}_{2} \mathrm{O}_{3} \\
(\%)\end{array}$ & $\begin{array}{l}\mathrm{CaO} \\
(\%)\end{array}$ & $\begin{array}{l}\mathrm{M}_{8} \mathrm{O} \\
(\%)\end{array}$ & $\begin{array}{l}\text { アル } \\
\text { カy } \\
(\%)\end{array}$ & 摘 要 \\
\hline B & 1460 & 15.53 & 79.81 & 0.43 & $0 . \therefore 5$ & 0.29 & 3.69 & \\
\hline $\mathbf{A}$ & 1500 & 17.39 & 80.93 & 0.54 & 0.26 & 0.25 & 0.63 & \\
\hline D & 1450 & 23.88 & 75.01 & 0.64 & 0.23 & 0.15 & 0.9 & \\
\hline R & 1350 & 57.60 & 39.52 & 0.99 & 0.79 & 0.42 & 0.68 & \\
\hline $\mathrm{K}$ & 1400 & 57.32 & 39.10 & 1.39 & 0.39 & 0,55 & $1.25\}$ & \\
\hline
\end{tabular}

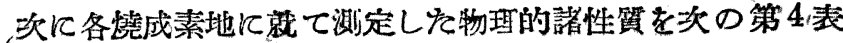
に示したが，ての結果より見ると各素地の吸水率文は氣孔率

第 4 表 燒成素地の物理的泾貿

\begin{tabular}{|c|c|c|c|c|c|c|}
\hline 符號 & $\begin{array}{c}\text { 吸水率 } \\
(\%)\end{array}$ & $\begin{array}{c}\text { 氣孔棌 } \\
(\%)\end{array}$ & 見掛 & 徼比重 & $\begin{array}{l}\text { 線膨張係數 } \\
\left.800^{\circ} \mathrm{C}\right)\end{array}$ & $\begin{array}{c}\text { 酎堡强度 } \\
\mathrm{kg} / \mathrm{om}^{2}\end{array}$ \\
\hline $\mathbf{B}$ & 9.34 & 17.82 & 2.97 & 2.67 & $\begin{array}{l}5.42 \times 10^{6} \\
(0.43 \%)\end{array}$ & 225 \\
\hline A & 9.88 & 18.64 & $3.48^{\circ}$ & 3.22 & $\begin{array}{l}6.97 \times 10=6 \\
(0.54 \%)\end{array}$ & 185 \\
\hline D & 9.52 & 17.94 & 3.16 & 2.83 & $\begin{array}{l}7.23 \times 10^{-6} \\
(0.56 \%)\end{array}$ & 206 \\
\hline $\mathrm{R}$ & 9.42 & 18.23 & 2.54 & 2.03 & $\begin{array}{l}7.61 \times 10^{-6} \\
(0.67 \%)\end{array}$ & 210 \\
\hline $\mathbf{K}$ & 8.86 & 17.79 & 2.23 & 1.92 & $\begin{array}{l}9.42 \times 10^{-6}-6 \\
(0.73 \%)\end{array}$ & 247 \\
\hline
\end{tabular}

第 1 表使用原料の化學成分及耐火度

\begin{tabular}{|c|c|c|c|c|c|c|c|c|}
\hline 原料名 化學成分 & $\begin{array}{c}\text { 灼驇減量 } \\
\text { \% }\end{array}$ & $\begin{array}{l}\mathrm{SiO}_{2} \\
(\%)\end{array}$ & $\begin{array}{c}\mathrm{Al}_{2} \mathrm{O}_{3} \\
(\%)\end{array}$ & $\begin{array}{c}\mathrm{Fe}_{2} \mathrm{O}_{3} \\
(\%)\end{array}$ & $\begin{array}{l}\mathrm{CaO} \\
(\%)\end{array}$ & $\begin{array}{l}\mathrm{MgO} \\
(\%)\end{array}$ & 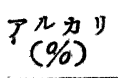 & 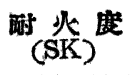 \\
\hline 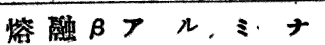 & 0.13 & 0.26 & 94.58 & 0.07 & 0.18 & 0.21 & 4.57 & 33 以上 \\
\hline 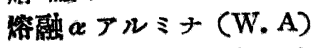 & - & 0.35 & 98.81 & 0.17 & 0.19 & 0.14 & 0.34 & 40 \\
\hline 㤩石ダイナスポア椵燒物 & 一 & 9.47 & 91.07 & 0.32 & 0.14 & 痕跡 & - & 38 \\
\hline 石 & 8.92 & 52.63 & 36.12 & 0.75 & 0.86 & 0.35 & 0.37 & 35 \\
\hline 叞 䙺 物 & - & 57.78 & 39.66 & 0.82 & 0.94 & 0.38 & 0.41 & - \\
\hline 本山木節 (冰籍物) & 15.33 & 48.60 & $\mathbf{3 3 . 0 7}$ & 1.17 & 0.31 & 0.48 & 1.04 & 33 \\
\hline 问上非 燒 物 & 一 & 57.39 & 39.06 & 1.38 & 0.37 & 0.57 & 1.23 & - \\
\hline 蛙目粘土(水筙物) & 12.87 & 49.48 & 34.45 & 1.25 & 0.54 & 0.31 & 1,10 & 34 \\
\hline
\end{tabular}




\begin{tabular}{|c|c|c|c|c|c|c|c|c|c|c|}
\hline 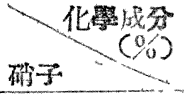 & $\mathrm{SiO}_{2}$ & $\mathrm{Al}_{2} \mathrm{O}_{3}$ & $\mathrm{Fe}_{2} \mathrm{O}_{3}$ & $\mathrm{~B}_{2} \mathrm{O}_{3}$ & $\mathrm{ZnO}$ & $\mathrm{P}_{\mathrm{D}} \mathrm{O}$ & $\mathrm{BaO}$ & $\mathrm{CaO}$ & $\mathrm{Na}_{2} \mathrm{O}$ & $\mathrm{K}_{2} \mathrm{O}$ \\
\hline BK 7 & 66.81 & 0.49 & 0.03 & 10.63 & - & 0.19 & 2.77 & 0.67 & 8.47 & 8.36 \\
\hline SF 2 & 40.75 & 0.12 & 0.03 & - & - & 51.13 & - & 0.13 & 0.61 & 6.93 \\
\hline SK 5 & 39.64 & $2 . c 6$ & 0.02 & 6.38 & 6.19 & - & 42.35 & 0.03 & 2.63 & 1.73 \\
\hline
\end{tabular}

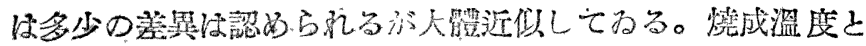

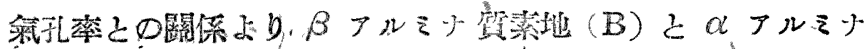

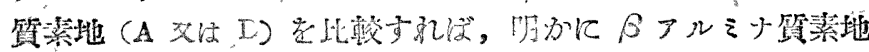

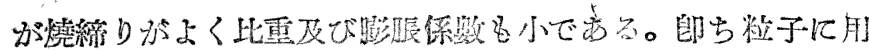

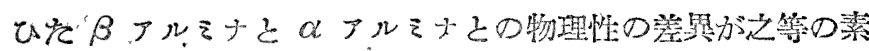
地にる明か儿現ほれて为る。

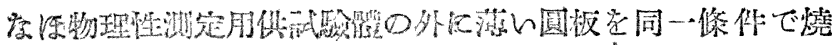

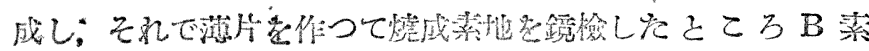

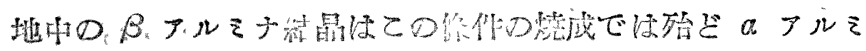

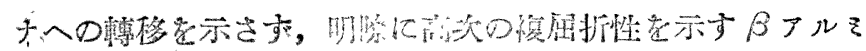

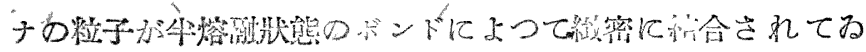

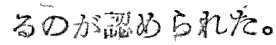

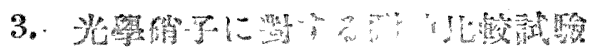

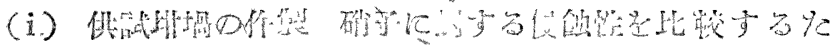

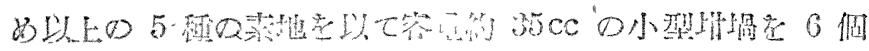

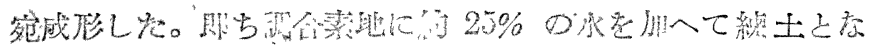

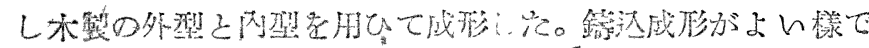

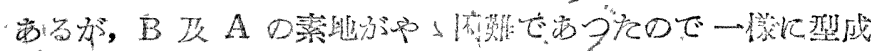

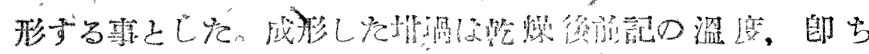
$B=1400^{\circ} \mathrm{C}, A=1500^{\circ} \mathrm{C}, D=1450^{\circ} \mathrm{C}, \mathrm{R}=1350^{\circ} \mathrm{C}, \mathrm{K}=1400$

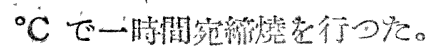

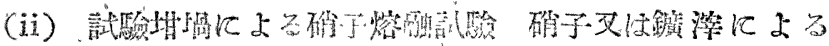

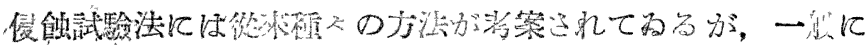

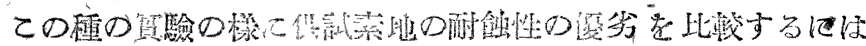

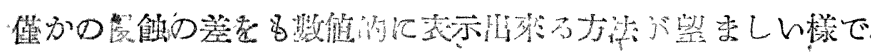

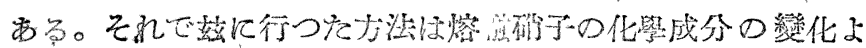

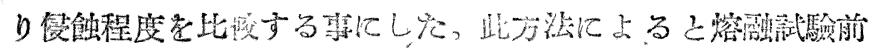

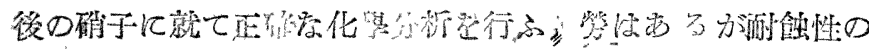

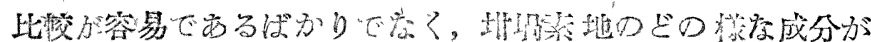

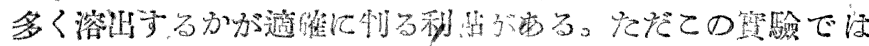

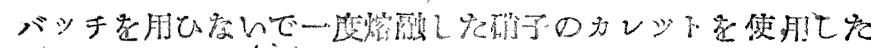

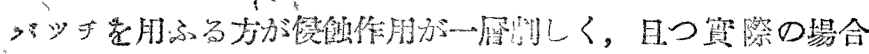

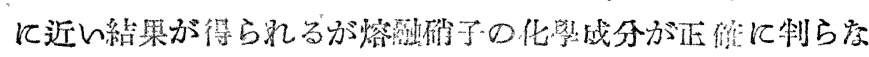

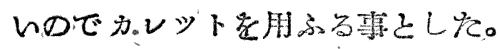

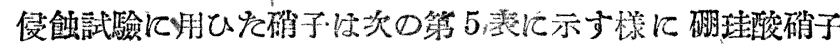
(BK 7), 重フリンド硝子( SF 2), 及び重バリウムクラウン

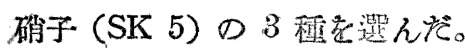

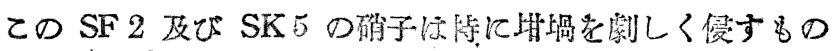
之さ机て居る。

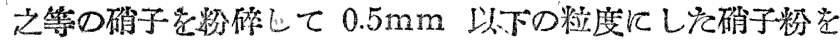

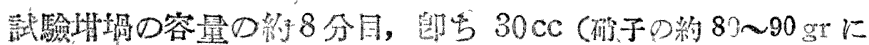

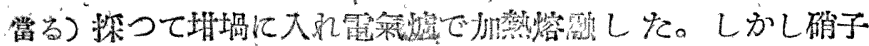

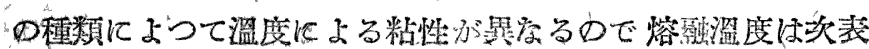

第 6 表江示与椄に BK $7=1350 . \mathrm{C}$, SF $2=1250^{\circ} \mathrm{C}$, SK $5=$ $1400^{\circ} \mathrm{C}$ としねが，大體之等の溫度で各硝子は類似の粘性を

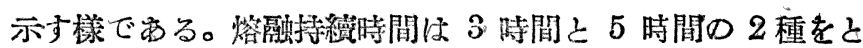

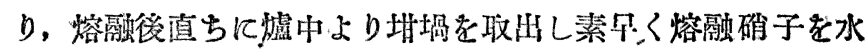
中に流し出した。

第 6 至 确子熔融 條件

\begin{tabular}{|c|c|c|c|}
\hline ：號 & 熔融溫度 & \multicolumn{2}{|c|}{ 熔属持窝時間 } \\
\hline 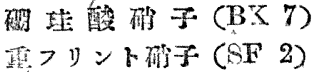 & $\begin{array}{r}1350^{\circ} \mathrm{C} \\
1250^{\circ} \mathrm{C}\end{array}$ & $\begin{array}{c}3 \text { hre. } \\
\text { " }\end{array}$ & $\begin{array}{c}5 \text { hrs. } \\
\text { " }\end{array}$ \\
\hline 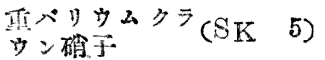 & $1400 \mathrm{C}$ & $"$ & $" \prime$ \\
\hline
\end{tabular}

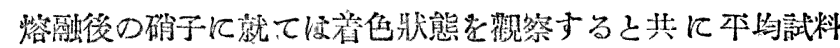

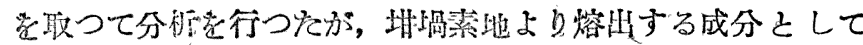

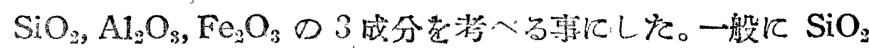

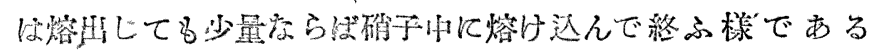

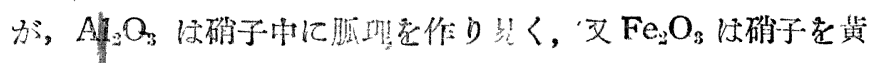

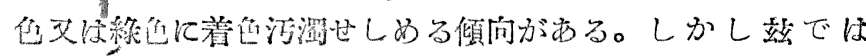

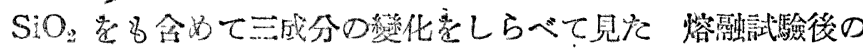
确于儿新々て行つた化學分析結呆を示せば次の第 7 表の如

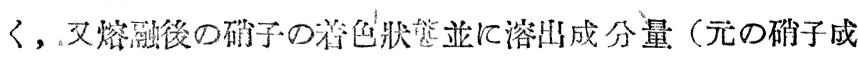
分之の落）を一括して表示す就ば 8 表の栐である。

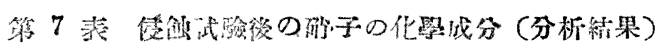

\begin{tabular}{|c|c|c|c|c|c|c|c|}
\hline \multirow{2}{*}{$\begin{array}{l}\text { 此 } \\
\text { 埥 }\end{array}$} & \multirow{2}{*}{$\begin{array}{l}\text { 試驗 } \\
\text { 矿子系 }\end{array}$} & \multicolumn{3}{|c|}{ 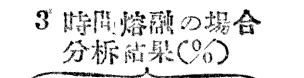 } & \multicolumn{3}{|c|}{$\begin{array}{c}5 \text { 旺間揢融の場合 } \\
\text { 分㭛維果 }(\%)\end{array}$} \\
\hline & & $\mathrm{SiO}_{2}$ & $\mathrm{Al}_{2} \mathrm{O}_{3}$ & $\mathrm{Fe}_{2} \mathrm{O}_{3}$ & $\mathrm{SO}_{2}$ & $\mathrm{~A}_{2}{ }_{2} \mathrm{O}_{3}$ & $\mathrm{~F}_{2} \mathrm{O}_{3}$ \\
\hline \multirow{3}{*}{$B$} & BK 7 & 67.97 & 0.86 & 0.34 & 6.06 & 1.01 & 0.63 \\
\hline & SF 2 & 42.05 & 0.88 & 0.20 & 43.28 & 1.02 & 0.46 \\
\hline & SK 5 & 41.23 & 3.79 & 0.56 & 42.66 & 5.38 & 0.59 \\
\hline \multirow{3}{*}{ A } & RK 7 & 68.15 & 0.95 & 0.47 & 68.70 & 1.11 & 0.90 \\
\hline & SR 2 & 43.14 & 1.75 & 0.43 & 44.45 & 2.38 & 0.36 \\
\hline & SK 5 & 42.61 & 5.25 & 0.38 & 43.87 & 7.19 & 0.99 \\
\hline \multirow{3}{*}{$\mathrm{D}$} & BK 7 & 69.55 & 1.21 & $0 . \angle 6$ & 70.45 & 2.14 & 0.60 \\
\hline & SF 2 & 44.71 & 1.86 & 0.37 & 46.05 & 4.29 & 1.29 \\
\hline & SK 5 & 44.70 & 5.17 & 0.71 & 45.38 & 8.70 & 1.68 \\
${$\hline${ \hline \multirow { 3 } { * }\multicolumn{2}{|c|}{\begin{array}{ll}\mathrm{BK} & 7 \\
\mathrm{SF} & 2 \\
\mathrm{SK} & 5\end{array}}}$ & 69.41 & 1.93 & 0.26 & 71.0 & 2.22 & 0.80 \\
\hline & & 46.48 & 3.43 & 1.05 & $47.6 \mathrm{~J}$ & 4.46 & 1.36 \\
\hline & & 45.01 & 5.01 & 1.29 & 45.74 & 9.06 & 1.66 \\
\hline \multirow{3}{*}{$\mathrm{K}$} & BK 7 & 70.04 & 2.26 & 0.51 & 71.88 & 2.91 & 1.00 \\
\hline & SH 2 & $47.7 ! 9$ & 3.93 & 1.87 & 49.09 & 4.91 & 2.27 \\
\hline & SK 5 & 45.94 & $6 \cdot 39$ & 1.33 & 46.29 & 9.57 & 1.88 \\
\hline
\end{tabular}

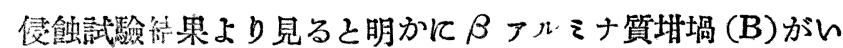
づれの硝子に對してをる最も强い耐蝕性を示し, 朋城の種類に 上る酎蝕性の順位ほ $B>A>D>R>K$ である。今 $\beta$ ァル

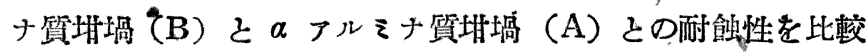

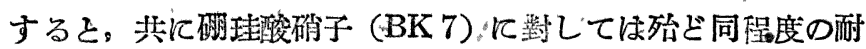
领性を示し優少の美はあまり認められ机いが, 侵蝕性の劇し 几 SF 2, 特に SK 5硝子に對しては B 朋堝が㴽が優れた 


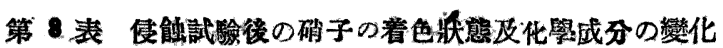

\begin{tabular}{|c|c|c|c|c|c|c|c|c|c|c|c|}
\hline \multirow{2}{*}{$\begin{array}{l}\text { 使 } \\
\text { 城 } \\
\text { 境 }\end{array}$} & \multirow{2}{*}{$\begin{array}{l}\text { 試 } \\
\text { 驗 } \\
\text { 硝 } \\
\text { 子 }\end{array}$} & \multicolumn{2}{|c|}{ 着色狀態 } & \multicolumn{8}{|c|}{3 续間熔融の場合 $(\%)$ 硝 } \\
\hline & & 3 時間 & 5，㭙間 & $\widehat{\mathrm{Al}_{2} \mathrm{O}_{3}}$ & $\overline{\mathrm{SiO}_{2}}$ & $\mathrm{Fe}_{2} \mathrm{O}_{3}$ & 郭 & $\widehat{\mathrm{SiO}_{2}}$ & $\mathrm{Al}_{2} \mathrm{O}_{3}$ & $\mathrm{Fe}_{2} \mathrm{O}_{3}$ & 部 \\
\hline \multirow{4}{*}{ B } & BK 7 & - & 淡、翼 & 1.16 & 0.37 & 0.31 & 1.84 & 2.25 & 0.52 & 0.60 & 3.37 \\
\hline & $\mathrm{SF} 2$ & - & - & 1.30 & 0.76 & 0.17 & .2 .23 & 2.53 & 0.90 & 0.43 & 3.86 \\
\hline & SK 5 & - & - & 1.59 & 0.83 & 0.34 & 2.76 & 3.02 & 1.16 & 0.37 & 4.55 \\
\hline & & & & & & & 6.83 & & & & 11.78 \\
\hline \multirow{4}{*}{ A } & BK 7 & - & 淡 黄 & 1.84 & .0 .46 & 0.44 & 2.24 & 1.89 & 0.62 & 8.87 & 3.38 \\
\hline & SF 2 & - & - & 2.39 & 1.63 & 0.40 & 4.42 & 3.70 & 2.26 & 0.33 & 6.29 \\
\hline & SK 5 & - & 淡 翼 & 2.97 & 2.29 & 0.36 & 5.62 & 4.23 & 2.73 & 0.97 & 7.93 \\
\hline & & & & & & & 12.28 & & & & 17.60 \\
\hline \multirow{4}{*}{ D } & BK 7 & - & - & 2.74 & 0.72 & 0.43 & 3.89 & 3.64 & 1.65 & 0.57 & 5.86 \\
\hline & SF 2 & - & 淡黄濁 & 3.46 & 1.74 & 0,34 & 6.04 & 5.30 & 2.17 & 1.26 & 8.73 \\
\hline & SK 5 & - & 淡黃綠 & 5.06 & 2.21 & 0.69 & $7: 96$ & 5.74 & 2.46 & 1.66 & 9.86 \\
\hline & & & & & & & 17.89 & & & & 24.45 \\
\hline \multirow{4}{*}{$\mathbf{R}$} & BK 7 & - & 淡黄濁 & 2.60 & 1.44 & 0.23 & 4.87 & 4.25 & 1.73 & 0.77 & 6.75 \\
\hline & SF 2 & 淡 黄 & 淡黄綠 & 5.73 & 3.30 & 1.02 & 10.05 & 6.85 & 4.34 & 1.33 & 12,52 \\
\hline & SK 5 & - & 淡黄綠 & 5.87 & 2.05 & 1,27 & 8.69 & 6.10 & 3.22 & 1.64 & 10.96 \\
\hline & & & & & & & 23.01 & & & & 30.23 \\
\hline \multirow{4}{*}{$\mathrm{K}$} & BK 7 & - & & 3.23 & 1.77 & 0.48 & 5.48 & 5.07 & 2.42 & 0.97 & 8.46 \\
\hline & SF 2 & 淡 涉 & 黄 濁 & 7.04 & 3.86 & 1.84 & 12.74 & 8.34 & 4.79 & 2.24 & 15.37 \\
\hline & SK 5 & 淡 黄 & 谓 緣 & 6.30 & 3.43 & 1.31 & 11.04 & 6.61 & 3.94 & 1.86 & 12.41 \\
\hline & & & & & & & 29.26 & & & & $33 ., 4$ \\
\hline
\end{tabular}

酎蝕性を示すのK對し，A 朋堝は夫等の硝子によつて比较的 多くの $\mathrm{Al}_{2} \mathrm{O}_{3}$ 汃揢出する事が制る。，ダイアスボ使用の D 坩堝もやはりコランダムが主成分で更るが，比较的多く侵さ

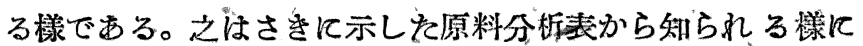
てのダイアスポフ秋は可な゙りの珪酸分を含む事に山るもの

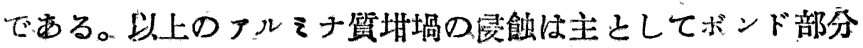
に於て起るるので, 粒子部分は此輬的安定であつて, 從つて 传玲は短時間に壮進行せ小時間の經過已共に次第に成分熔出

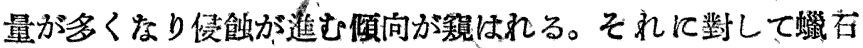

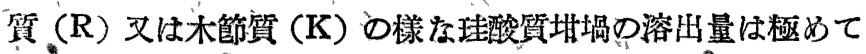

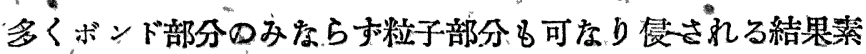
地組織が多孔質化し一展侵刢が促進される傾向がある。

\section{4. $\beta$ アルミさ質坩堝の耐強性に就て}

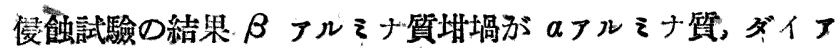
スポ質又は粘士質坦堝て此べて硝子て對する耐蝕性が優れ

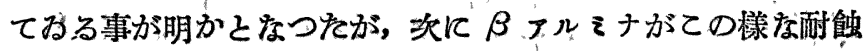
性者す理由を少しく教察して見る事とした。一般に堵堝が 高溫度に於て, 熔融硝子之接觸する場合蒙る侵蝕作用は色々

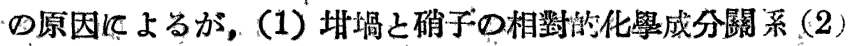
坩堝素地の緻密度，及び (3) 硝子の粘性の三因子によDて大 きな支配を受りるものである。ての研究で行つね侵蝕比較試 驗て於ては各埋堝素地の莱扎率及び硝子の粒性を略タ一定に して行うたから，玄では侵蝕過程中て起り得る坩堝素地之硝 子と口化學反應及び夫件ふ組織の變化が考へられる。

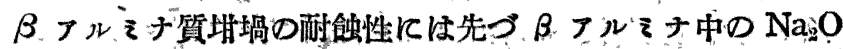

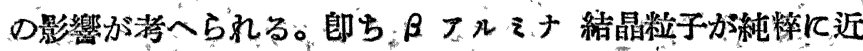

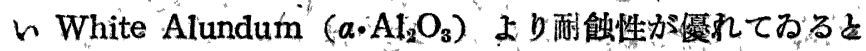

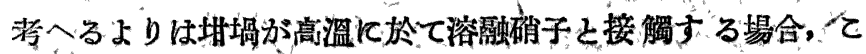
๑ $\mathrm{Na}_{2} \odot$ の存在によってその境界面に一㮔の保護唇が形成さ
れるものと考へる功没當しある。今 $\mathrm{Na}_{3} \mathrm{O}-\mathrm{Al}_{2} \mathrm{O}_{3}-\mathrm{SiO}_{2}$ 系 几於ける化合物として Nephelite $\left(\mathrm{Na}_{2} \mathrm{O} \cdot \mathrm{Al}_{2} \mathrm{O}_{3} \cdot 2 \mathrm{SiO}_{2}\right)$ 教

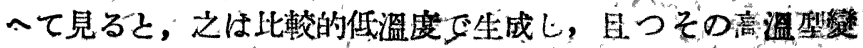

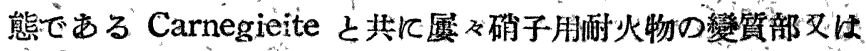

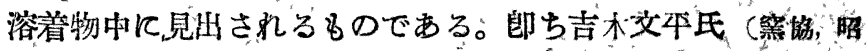

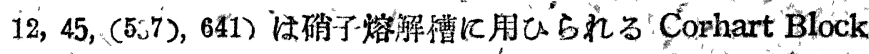

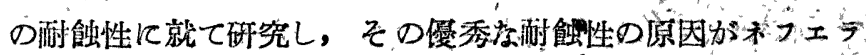

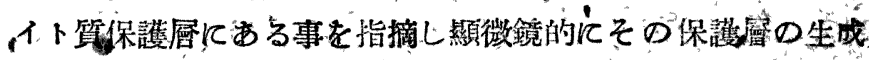
を倠め, 过 D. S. Beliankin \& M. A. Besborodov (Jour. A.m. Ceram. Sò̀., 1930, 13, 346 35.3) 及 H. Insley (Jour.

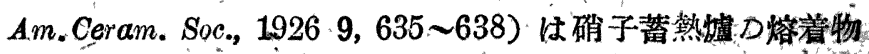
の主要鉱物が Nephelite 及び Carnegieite した。吉木氏の報告に上れば，高溫に於て Corhart が曹迬石 灰挂股硝子之接触する場合, Mullite $\left(3 \mathrm{Al}_{2} \mathrm{O}_{3} \cdot 2 \mathrm{SiO}_{\mathbf{2}}\right)$ D解離 そよつて生じた Corundưm 微晶が硝子中のアルカウと反應 して Nephelite $\left(\mathrm{Na}_{2} \mathrm{O} \cdot \mathrm{Al}_{2} \mathrm{O}_{3} \cdot 2 \mathrm{SiO}_{2}\right)$ 支中間生成物として

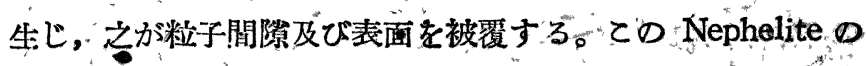
高溫で於ける粘性は硝子に比べて甚を゙太ですつてての粘寒 の差がコランダム面に於けるネフエライト被覆層を安是に保

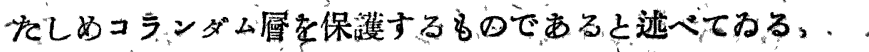

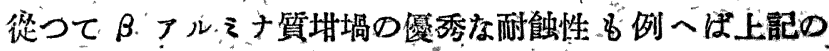

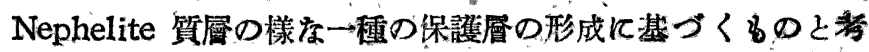
ヘられる。

\section{5 . 要旨}

$\beta$ アルラナの工業的利用法として

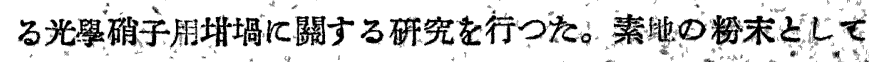

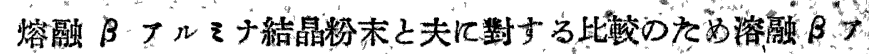

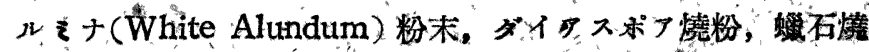

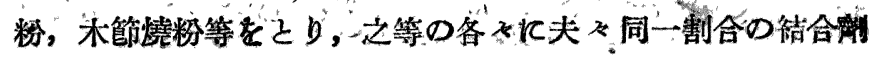




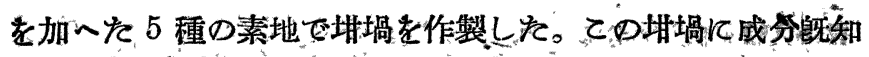

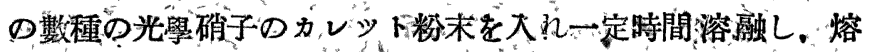

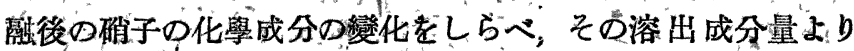

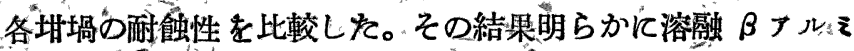

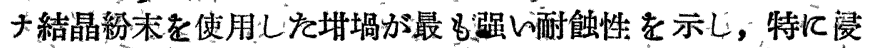
蝕性の劇しい重フリント硝子及重バリウムクラウン硝子に對 して强々抵抗を示した。

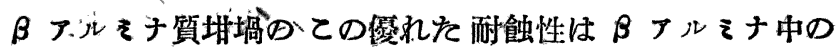

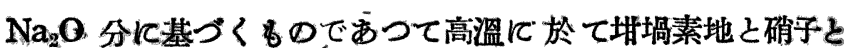

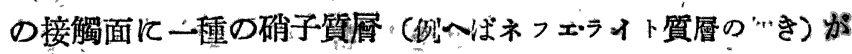
形成され之が确子の侵赨比對して保護作用を高するのと思性 和。

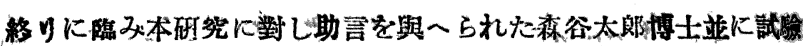

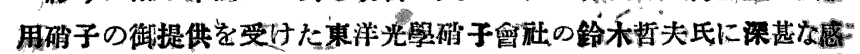

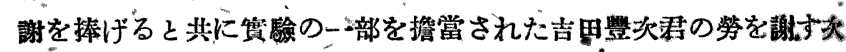

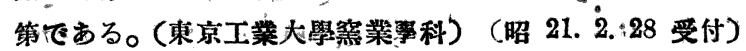

\section{耐火物に及ぼ・す墭素瓦斯の作用 \\ 山冈俊 呰・河井信 雄・河原田次㴊}

\section{緒言}

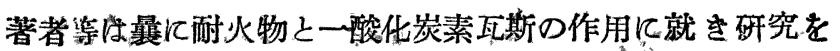
行ひ、その作用, 經渦を知 D得たのであるが, 金屬マグネシ ウムの電解其他監素發生の高溫度工業に隔膜又は爐材として

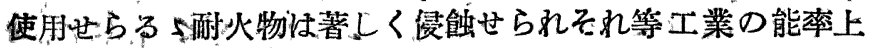

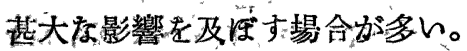

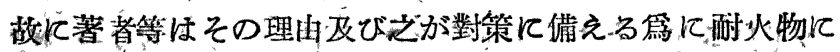
及底主監素瓦斯の作用沉つ记研究するの必要を痛感し本研 究意進めた。

$\mathrm{Mgcl}_{2}$-耐灭物閒の作用に關しては A. T. Green 氏等によ

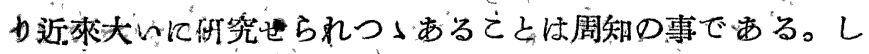

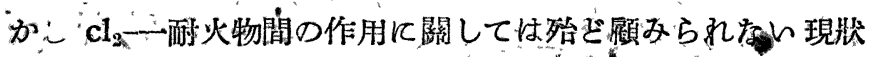

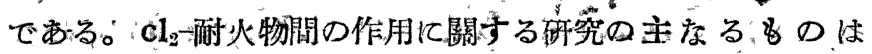
Stuart M. Phelps, Amr. Ref. Jour. Büll 1927, [9], 8). Rock Prod, 1927, 30，[15]，67)等Ф研究がある。てれによれば

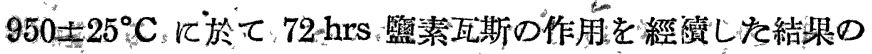

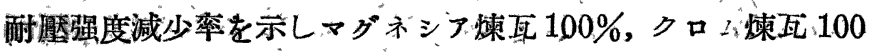

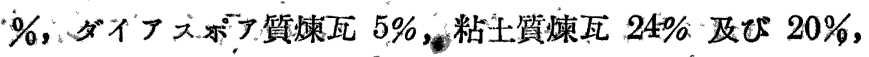
球石煉瓦 $13 \%$ ，の減少率で,,ク口儿㛐瓦の場合には chromic

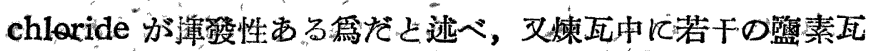

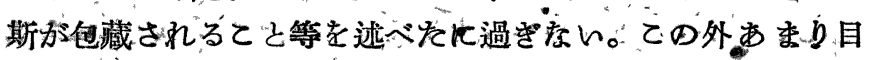
立つ報告は見當らない樣である。そこで著者等は更に之等

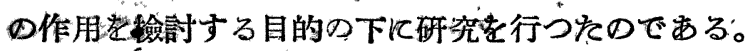

從乘著著等方洏灭物一瓦斯間の反應菜に於て主張してきた 間題俚

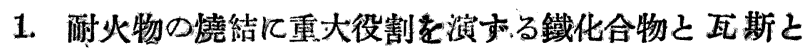
の作用.

2. 耐火物中に包合せられる氣孔の量と瓦斯躼蝕の程度

3. 耐火物構成化合物之瓦斯之の作用(觸煤性むるもの, 化學作用老旺するむの).

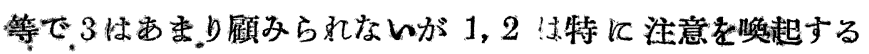
必要がある。

(1) 耐火物つ各成分鏣物の結合飞對乙て重要役割を演じて るる鐵化合物 (假程) 以還元性瓦斯てよる作用最し著しく之等
鐵化合物々瓦斯之の作：により結合能力の減退によつて耐火 物》崩解照來するととは一酸化炭素瓦斯の作用に於て子明

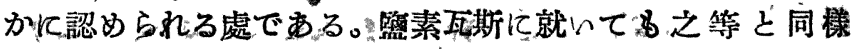

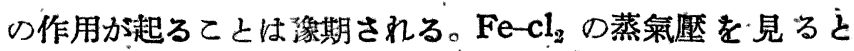

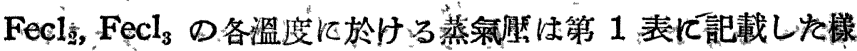

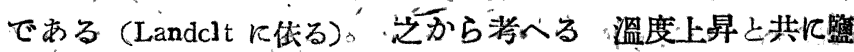
化鐵蒸雨壓著し〈上昇し容易汇低溫度で揮發世られる事を 知り得るのである。

\begin{tabular}{|c|c|c|c|c|c|}
\hline & F. $\mathbf{c}_{2}$ & & & $\mathrm{Fecl}_{3}$ & \\
\hline $\left.\mathrm{T}^{\circ} \mathrm{C}\right)$ & $\mathbf{P}(\mathrm{mm})$ & $\mathrm{B} \in \mathrm{m}$ & $T\left(0^{\circ} \mathrm{C}\right)$ & $P(\mathrm{~mm})$ & Bam \\
\hline 68.94 & 12.0 & flussig & 216.44 & 3.9 & feșt \\
\hline 72.14 & 29.5 & " & 237.64 & 13.5 & "I \\
\hline $781,94^{\circ}$ & 47.1 & " & $262: 44$ & $53 .{ }^{\circ}$ & ill \\
\hline 83.64 & 88.7 & Ir & 284.9 & 162.5 & $"$ \\
\hline 883.44 & 172.8 & $"$ & 299.54 & 340,9 & $"$ \\
\hline 994.84 & $593: 0$ & $\|$ & $3 \times 4.64$ & 451.9 & $" \prime$ \\
\hline \multirow[t]{2}{*}{ 1.023.84 } & 76.0 & $"$ & 313.24 & $729: 6$ & $\mathbf{f} \mathbf{u}_{\text {ssig }}$ \\
\hline & & & 318.34 & 872.6 & $"$ \\
\hline
\end{tabular}

$\mathrm{Fecl}_{2}$ 及び $\mathrm{Fecl}_{3}$.の蒸氣壓を見る゙と $\mathrm{Fecl}_{3}$ 快著しく低溫で

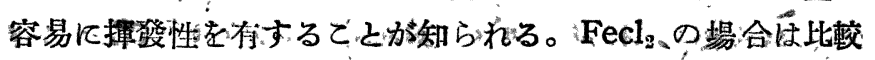

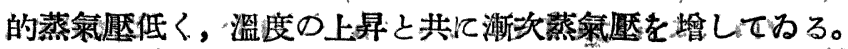

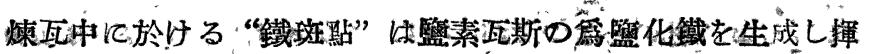

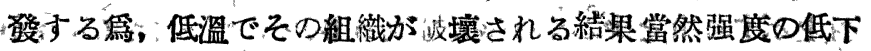

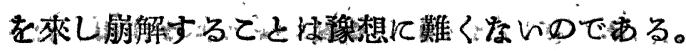

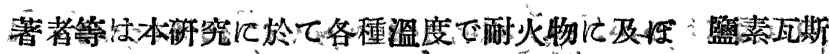

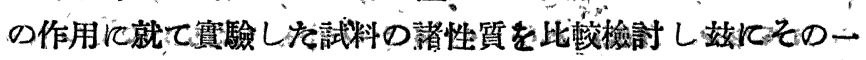

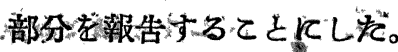

\section{I. 独 溤 法}

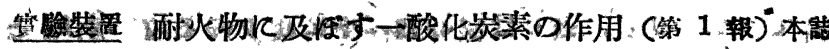

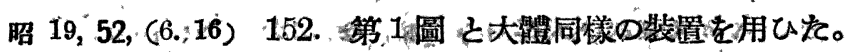

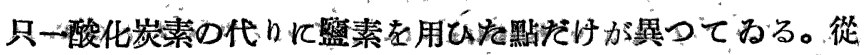

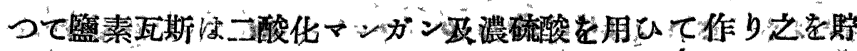

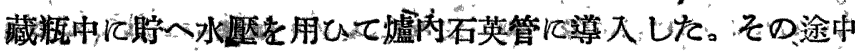

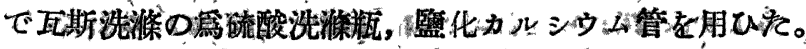

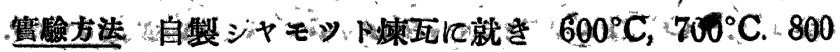

